\author{
Б. О. Блюсс /Д. т. н./, С. В. Дзюба /к. т. н./, \\ Є. В. Семененко /Д. Т. н./
}

Інститут геотехнічної механіки

ім. М. С. Полякова НАН України, м. Дніпро,

Україна

e-mail: sergejdzuba@gmail.com

\title{
Обґрунтування параметрів ефективності гідротехнічних систем у технологіях переробки мінеральної сировини
}

B. O. Blyuss /Dr. Sci. (Tech.)/, S. V. Dziuba /Cand. Sci. (Tech.)/, Ye. V. Semenenko /Dr. Sci. (Tech.)/
Polyakov Institute of Geotechnical Mechanics of National Academy of Sciences of Ukraine, Dnipro, Ukraine

e-mail: sergejdzuba@gmail.com

\section{The rationale of the parameters of the efficiency of hydraulic systems in the processing of mineral raw materials}

\begin{abstract}
Мета. Обгрунтування параметрів ефективності фрункціонування гідротехнічних систем у технологіях видобутку і переробки мінеральної сировини з урахуванням сучасних можливостей інтенсифрікації процесів переробки корисних копалин.

Методика. Аналіз результатів дослідження режимів роботи гідротехнічних систем підприємств гірничо-металургійної галузі дозволив обгрунтувати параметри гідравлічних процесів у технологіях переробки мінеральної сировини з метою підвищення ефективності параметрів збагачувального устаткування і зниження собівартості готового концентрату.

Результати. Обгрунтовано параметри ефективності гідротехнічних систем підприємств гірничо-металургійної галузі України, а саме в результаті розвитку методів оцінки ефрективності гідротранспортного комплексу гірничо-переробних комбінатів запропоновано характеризувати надійність постачання продукції і збереженість системи трубопровідного транспорту величиною показника гідравлічної надійності.

Наукова новизна. На основі методів оцінки економічної ефрективності гідротехнічних систем технологій переробки мінеральної сировини, вихідними принципами якої є: комплексність оцінки; комерційний підхід; застосування адекватних параметрів визначення ефрективності на різних організаційних рівнях; урахування чинника часу і фрактора невизначеності запропоновано інтегральний показник, а саме показник гідравлічної надійності.

Практична значущість полягає у введенні показників, а саме: гідравлічної надійності і режимів транспортування в гідротехнічних системах у систему моніторингу технологій переробки мінеральної сировини, що забезпечує безперервний контроль в автоматичному режимі з урахуванням можливих не прогнозованих змін властивостей середовища, що перекачується, продуктивності та інших параметрів, оскільки величина втрат напору виражається через гідравлічний ухил, що залежить від швидкості і щільності гідросуміші, яка транспортується. (Іл. 1. Бібліогр.: 9 назв.)
\end{abstract}

Ключові слова: гідротехнічні системи, технології збагачення мінеральної сировини, коефрічієнт гідравлічної надійності, економічна ефрективність.

Вступ. Проблема зі складуванням відходів технологій переробки мінеральної сировини на комбінатах гірничо-металургійної галузі країни $\epsilon$ однією з основних при прийнятті управлінських рішень керівництвом для забезпечення ефективного функціонування і менеджменту. При відкритій розробці родовищ корисних копалин основна маса відчужених земель зайнята кар'єрами, відвалами та хвостосховищами. Так, загальна площа земельного відводу для п'яти гірничо-збагачувальних комбінатів у Кривому Розі становить більше двадцяти п' яти тисяч гектарів,
3 них більше семи тисяч гектарів займають відстійники і хвостосховища [1]. Хвостосховища гірничих підприємств є складними гідротехнічними спорудами, насамперед екологічно небезпечного і руйнівного характеру, які завдають шкоду навколишньому середовищу. Сучасні схеми внутрішньофабричного водообороту технологій переробки мінеральної сировини передбачають значне скорочення витрат на перекачування хвостів і освітленої води. При цьому основним напрямом у сфері інтенсифікації гідравлічних процесів у технологіях збагачення мінеральної 
сировини (ТЗМС) є вдосконалення обладнання і його технічних вузлів [2;3]. Так, для відділення шламу від зернистої частини перед основними процесами збагачення, тобто для класифікації та зневоднення, застосовують плоскі і дугові сита. Залежно від способу подачі пульпи, ці сита можуть бути напірними, при подачі пульпи від насоса під тиском, або ж безнапірним, при подачі пульпи самопливом з ємності [3].

Також важливим чинником $є$ вибір параметрів системи складування відходів ТЗМС безпосередньо на бортах пляжу намиву хвостосховищ. Так, при відомих параметрах системи гідротранспортування для вибору параметрів системи складування використовують залежності для знаходження кута нахилу струменя пульпи з концентрацією пасти до горизонту, які дозволяють визначити дальність польоту струменя і максимальну висоту іï підйому з урахуванням розміщення випускного трубопроводу на дамбі обвалування (рис. 1).

Аналіз і обгрунтування показників ефективності гідротехнічних систем показує, що ці показники є універсальною соціально-економічною категорією, яка характеризується об'єктивними причинно-наслідковими або стохастичними зв' язками і співвідношеннями між витратами і затратами, які підлягають регулюванню з метою оптимізації процесів виробництва на різних його рівнях [4].

При глобальному розгляді ефективність гідротехнічних систем технологій збагачення мінеральної сировини (ГСТЗМС) - це комплекс технологічних, екологічних, економічних і соціальних факторів, які об' єктивно впливають на економічну рентабельність виробництва, що реалізується в процесі через створення належних умов, модернізації технології і впровадження нових засобів і устаткування.

Технологічні фактори являють собою заходи щодо підвищення продуктивності технологічного та допоміжного обладнання, що використову-

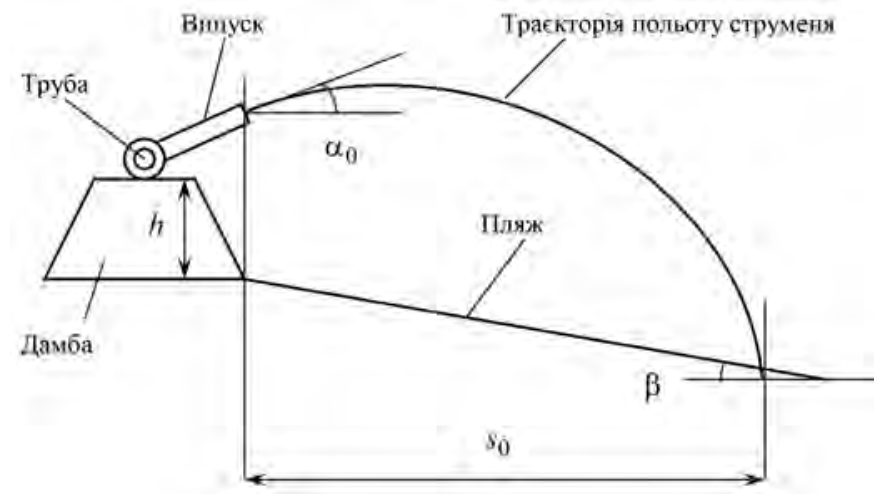

Рис. 1. До розрахунків дальності польоту струменя пульпи з концентрацією пасти при складуванні iii на поверхню пляжу намиву з верхнього майданчика дамби обвалування ється; скорочення споживання енергоресурсів; оптимізації графіків і режимів роботи підрозділів і системи в цілому. Для оцінки технологічної ефективності ГСТЗМС найбільш раціональним $\epsilon$ використання методів, що базуються на фундаментальних термодинамічних принципах, що дозволяють застосування ідеального або ідеалізованого аналога досліджуваних процесів [5]. Це дозволяє оцінити максимально можливу ефективність і межу зниження споживаної енергії, а використання аналогів з різним ступенем ідеалізації дозволяє гнучко адаптувати його до особливостей різних завдань. Наприклад, у теплоенергетиці граничним ступенем ідеалізації є цикл Карно, який визначається тільки температурами гарячого та холодного джерел теплоти, проте крім цього застосовуються цикли Ренкіна, Отто, Дизеля, які враховують вид і фізичні властивості робочого тіла, яке використовується [5].

Екологічні фактори, крім заходів з відновлення необхідного стану водного басейну і стану земельного ландшафту, визначаються вимогами і обмеженнями на утримання у відходах збагачення шкідливих речовин, викиди в атмосферу, обов' язковістю заходів щодо захисту навколишнього середовища.

Економічні фактори являють собою безпосередньо результати і витрати в процесі виробництва, зазвичай у вартісній, а за необхідності і в речовій формі. При оцінці ефективності враховуються витрати, які класифікуються за тимчасовою ознакою. Економічні фактори враховуються прямим рахунком на основі відповідних показників і нормативів.

При оцінці ефективності ГСТЗМС соціальні фактори враховуються в трьох основних формах: система обмежень на техніку, технологію і організацію будівництва і функціонування системи, що виражається соціальними стандартами умов праці та життя. Витрати, пов'язані $з$ дотриманням цих стандартів, можуть відрізнятися в порівнюваних варіантах і підлягають обліку в розрахунках ефективності.

Виділяють три основні економічні категорії, які визначають ефективність - витрати, результати, час [4]. При оцінці ефективності ГСТЗМС вихідними принципами є: комплексність оцінки; комерційний підхід; застосування адекватних методів визначення ефективності на різних організаційних рівнях; облік чинника часу і фактора невизначеності.

Комплексність оцінки передбачає врахування максимальної кількості факторів і умов, а також параметрів впливу, що забезпечує достовірність і надійність визначуваних критеріїв.

Комерційний підхід до оцінки ефективності означає, що об'єкт оцінки повинен бути ефек- 
тивний не тільки в межах певного технологічного підрозділу, а й сприятиме підвищенню ефективності всієї ГСТЗМС.

Принцип застосування адекватних методів визначення ефективності на різних організаційних рівнях означає, що при розрахунках ефективності заходів застосовуються діючі відпускні ціни на матеріали і обладнання, ставки заробітної плати, транспортні тарифи.

Одним з принципів, найбільш значущих у ринкових умовах при оцінці ефективності, $є$ врахування фактора часу в різних його формах і проявах. Класифікація витрат за тимчасовою ознакою дозволяє врахувати при оцінці ефективності ешелонування капітальних вкладень і введення в дію потужностей, різні за роками обсяги транспортної роботи, зміни собівартості, цін і тарифів, переключення вантажів з одного на інший види транспорту.

Невизначеність витрат і результатів при оцінці ефективності гідротранспортної системи об'єктивно зумовлена неповною інформацією на стадії розробки про умови будівництва трубопроводів, про техніку і технології ГСТЗМС, невизначеністю перебігу інвестиційного процесу, відсутністю досвіду будівництва і експлуатації таких систем. Усе це поки не дозволяє надійно оцінювати їх оптимальні і разом 3 тим реальні техніко-економічні показники.

Виділяють порівняльну і абсолютну ефективність [4]. Вибір оптимального варіанта при проектуванні або модернізації системи здійснюється на основі показника порівняльної економічної ефективності - приведених витрат. Потім проводиться оцінка абсолютної економічної ефективності обраного варіанта і здійснюється його перевірка на стійкість при різних нормативних коефіцієнтах ефективності.

Критерієм при визначенні порівняльної економічної ефективності капітальних вкладень є мінімум приведених витрат. Вихідними даними для визначення показників порівняльної економічної ефективності капітальних вкладень є: необхідний річний обсяг видобутку і транспортування, характеристика пульпи, відстань до відстійників і до кар'єрного поля і характеристика траси, техніко-економічні показники обладнання, кошторисні норми, укрупнені показники капітальних вкладень, прейскуранти оптових цін, нормативи для розрахунків експлуатаційних витрат.

При оцінці абсолютної ефективності на різних організаційних рівнях застосовуються різні критерії ефективності: на рівні технологічного підрозділу - зниження витрат на виконання технологічної операції або ії собівартості, на рівні ГСТЗМС - чиста продукція або прибуток підприємства, собівартість продукції, рентабельність.
3 огляду на це пропонується такий алгоритм оцінки ефективності ГСТЗМС: оцінюють ефективність системи при вихідних даних, заданих у формі інтервалів; визначають інтервали, за яких нова техніка стає економічно конкурентоспроможною у відношенні до еталонної; оцінюють ймовірність отримання очікуваних результатів; проводять перевірку результатів розрахунку ефективності на стійкість.

Перевірка результатів розрахунку на стійкість проводиться в статичній та динамічній постановках. У статичній постановці - шляхом визначення величини приведених витрат при різних коефіцієнтах ефективності, при цьому різниця приведених витрат не повинна змінювати знак. У динамічній постановці завдання - шляхом визначення інтегрального ефекту за різні розрахункові періоди, 5 або 15 років, термін служби системи, контрольний термін інвестиційної угоди.

При оцінці ефективності модернізації технології або впровадження нової техніки виявляють технічні фактори ефективності та форми прояву ix через економічні чинники, визначають новизну технічних рішень або ж перевіряють їх відповідність кращим світовим і вітчизняним досягненням. У цьому випадку фактор часу враховується дисконтуванням витрат і результатів при порівнянні варіантів, що розрізняються термінами досягнення поставленої мети і розподілом витрат у часі, забезпеченням сумісності варіантів, що розрізняються тривалістю модернізації і експлуатації, вирішенням завдань у статичній та динамічній постановці.

При статичній постановці завдання розрахунок ведеться на основі показників, віднесених до одного моменту часу: зазвичай перший рік функціонування системи або середній типовий рік. Динамічна постановка завдання означає розрахунок на основі показників за розрахунковий період - період між змінами основних параметрів, прогнозований період, термін служби системи або інший термін.

Інтегральний ефект являє собою суму результатів функціонування гідротранспортних систем за роками за розрахунковий період. Інтегральні витрати - сума витрат на створення і експлуатацію цих систем за роками за розрахунковий період. До складу інтегральних витрат входять дисконтовані за роками капітальні вкладення, поточні витрати без амортизаційних відрахувань, витрати на капітальний ремонт за вирахуванням ліквідаційного сальдо, основних виробничих фондів протягом розрахункового періоду і залишкової суми основних фондів після закінчення розрахункового періоду.

Таким чином, принципи оцінки ефективності розкриваються через систему методичних при- 
йомів, що реалізуються в практиці розрахунків при проектуванні ГСТЗМС, оцінці порівняльної ефективності модернізації технології і виборі варіантів нової техніки, визначенні граничних величин техніко-економічних показників.

При оцінці абсолютної ефективності ГСТЗМС використовують локальні і глобальні показники. Локальні показники ефективності визначають 3 умови мінімуму витрат або споживання ресурсів окремо взятого елемента системи, наприклад мінімуму питомої енергоємності гідротранспортного комплексу. Глобальні показники визначають 3 умови мінімуму витрат всієї системи, при цьому значення глобальних показників ефективності можуть не збігатися з локальними показниками. Якщо значення цих показників для всіх елементів збігаються, то система вважається абсолютно оптимізованою. Якщо немає - то система вважається оптимізованою глобально. Якщо ефективні показники були обрані тільки для деяких елементів системи, то така система вважається елементарно оптимізованою. Якщо значення глобальних показників ефективності для деяких елементів системи є неприпустимими, неможливими або визначають для неї не розрахункові, що не ефективні або ненадійний режими роботи, то така система є неефективною і потребує узгодження параметрів елементів. У деяких випадках раціональною є вибіркова оптимізація системи, коли обирається елемент або група елементів системи, експлуатація яких обумовлює найбільші витрати, і для них визначаються локальні показники ефективності.

Постановка завдання. Економічна ефективність гідротехнічних систем грунтується на відповідності обраного режиму транспортування мінімальним видам витрат, як основних, визначених умовами транспортування, так і непрямих, обумовлених впливом зміни параметрів транспортування на технологічний процес, елементом якого є певна транспортна установка [6].

Оцінка ефективності роботи гідротранспортних установок проводиться на основі трьох показників - питомий натиск, питома витрата енергії і енергоємність гідротранспортування [5]:

$$
i_{\Pi}=\frac{H}{L} ; \quad \exists=\frac{\Delta i}{367 C \rho_{T}} ; \quad E=\frac{\rho_{S} i L}{C},
$$

де відповідно $H$ і $L$ - сумарний напір насосів гідротранспортного комплексу і довжина транспортування; $\Delta i, i$ - додатковий гідравлічний ухил, питомі втрати напору; $\rho_{S}, C$ - щільність твердого матеріалу, об'ємна концентрація гідросуміші.

Подальші дослідження показали, що питома [кВт·рік/(т·км)] енергоємність гідротранспортної системи може бути подана у вигляді добутку двох величин [6]:

$$
e=A B ; \quad A=\frac{g}{3,6 \rho_{S}} ; \quad B=\frac{\rho i}{C},
$$

де відповідно $A$ і $B$ - постійний коефіцієнт, що залежить від заданої продуктивності гідротранспортної системи за твердим матеріалом і змінний параметр, наведена щільність; $\rho$ - щільність гідросуміші.

Для будь-якого стратифікованого потоку із заданою продуктивністю за дискретною фазою існує єдине співвідношення кінематичних параметрів течії і концентрації дискретної фази, що враховуються критерієм, який задовольняє найменшим значенням енергоємності процесу транспортування і найбільшій його ефективності [6].

Параметр $B \in$ спадаючою-зростаючою функцією в інтервалі зміни концентрації твердої фази і має мінімум при певному значенні, яке залежить від механічних характеристик твердих частинок i їх щільності. Для кожного виду гідросумішей i продуктивності гідротехнічної системи є свій мінімум параметра $B$, що відповідає оптимальному значенню концентрації твердої фази. У зв'язку 3 цим параметр, що розглядається, приймається за критерій оптимальної величини концентрації дискретної твердої фази і мінімуму енергоємності гідротранспортної системи відповідно до формули (2). Характер зміни $B$-критерію говорить про те, що при значеннях концентрації, менших за екстремальне значення, функція $B(C)$ - спадна, а в інтервалі концентрацій, більших за це значення, - зростаюча. Значення концентрації в екстремальній точці відповідає мінімуму функції $B(C)$ i, відповідно, енергоємності $e$, а також необхідній потужності, що витрачається грунтовим насосом.

Аналіз експериментальних даних і результатів перерахунку на продуктивності системи на 368 i 100 т/ч твердого матеріалу показує, що критерій зі збільшенням концентрації гідросуміші зменшується, але з зростання щільності гідросуміші від 1400 до 3450 кг / м³ збільшується пропорційно збільшенню щільності твердого матеріалу [7]:

$$
B_{\min }=0,0018 \frac{\rho_{S}^{1,1462}}{C^{0,967}} .
$$

Ці результати дозволяють рекомендувати для оцінки ефективності порівнювати існуючу енергоємність 3 ії мінімальним для розглянутих умов значенням:

$$
K_{e}=\frac{556 i \rho_{\mathcal{M}}}{C^{0,033} \rho_{S}^{1,1462}} .
$$

Ефективність роботи гідротранспортних установок і установок оборотного водопостачання у відношенні до проектного режиму роботи спочатку оцінювалася коефіцієнтом гідравлічної ефективності [8]: 


$$
E=\sqrt{\frac{\lambda_{0}}{\lambda}}
$$

де $E$ - коефіцієнт гідравлічної ефективності;

$\lambda_{0}$ i $\lambda$ - теоретичне і фактичне значення коефіцієнта гідравлічного опору тертя.

У результаті розвитку методів оцінки ефективності було запропоновано характеризувати надійність постачання продукції і збереженість системи трубопровідного транспорту величиною показника гідравлічної надійності [9]:

$$
J_{H}=\frac{\rho_{i}}{\rho_{0}} \frac{Q_{i}}{Q_{0}} \frac{H_{i}}{H_{0}},
$$

де відповідно $\rho_{i}$ і $\rho_{0}$ - значення щільності середовища, що перекачується, в $i$-й період і на початок експлуатаціі;

$Q_{i}$ i $H_{i}$ - продуктивність установки і втрати напору на ділянці в $i$-й період часу;

$H_{0}$ - втрати напору на ділянці на початок експлуатації.

Для оцінки запасу гідравлічної надійності у відношенні до проектного значення як $Q_{i}$ необхідно прийняти допустимі або дійсні значення показників режиму в трубопроводі:

$$
J_{D}=\frac{\rho_{D}}{\rho_{0}} \frac{Q_{D}}{Q_{0}} \frac{H_{D}}{H_{0}},
$$

де відповідно $\rho_{D}$ i $Q_{D}$ - допустиме значення щільності середовища, що перекачується, і продуктивність установки;

$H_{D}$ - допустимі втрати напору на ділянці.

Введення показників $J_{H} \mathrm{i} J_{D}$ в систему моніторингу забезпечує безперервний контроль в автоматичному режимі з урахуванням можливих не прогнозованих змін властивостей середовища, що перекачується, продуктивності та інших параметрів, оскільки величина втрат напору виражається через гідравлічний ухил, що залежить від швидкості і щільності континууму, який транспортується [9]:

$$
J_{H}=\frac{\rho_{i}}{\rho_{0}} \frac{Q_{i}}{Q_{0}} \frac{i_{D}}{i_{0}}
$$

де відповідно $i_{D} \mathrm{i} i_{0}$ - гідравлічний ухил в $i$-й період часу і на початок експлуатації.

При транспортуванні води або іншої однорідної рідини, коли застосовується ступеневий закон опору [9]

$$
H_{i}=\beta_{i} \frac{Q_{i}^{2-m} v_{i}^{m}}{D_{i}^{5-m}}
$$

формула (8) у разі транспортування гідросуміші може бути переписана у вигляді:

$$
J_{H}=\left(\frac{\rho_{i}}{\rho_{0}}\right)\left(\frac{\beta_{i}}{\beta_{0}}\right)\left(\frac{v_{i}}{v_{0}}\right) \frac{1+k_{D}}{1+k_{0}}\left(\frac{Q_{i}}{Q_{0}}\right)^{3-m}\left(\frac{D_{0}}{D_{i}}\right)^{5-m},
$$

де відповідно $\beta_{i}$ і $\beta_{0}$ - коефіцієнт пропорційності в $i$-й період часу і на початок експлуатації; $\mathrm{v}_{i} \mathrm{i} \mathrm{v}_{0}$ - кінематичний коефіцієнт в язкості середовища в $i$-й період часу і на початок експлуатації;

$k_{D}$ i $k_{0}$ - відносний додатковий гідравлічний ухил в $i$-й період часу і на початок експлуатації;

$D_{0}$ i $D_{i}$ - діаметр трубопроводу на початок експлуатації і в $i$-й період часу;

$m$ - показник ступеня в залежності втрат напору від витрати.

У роботі показано, що застосовуваний на практиці коефіцієнт гідравлічної ефективності $E(5)$ може розглядатися як частковий розв' язок рівняння (6) [9]. При цьому аналіз режимів експлуатації гідротехнічних систем із застосуванням $J_{H}$ забезпечує істотно більшу чутливість до зміни експлуатаційних параметрів (наприклад, продуктивність), ніж коефіцієнт гідравлічної ефективності $E$ [8; 9].

Висновки. Гідротехнічні системи технологій збагачення мінеральної сировини проаналізовані як один із основних об'єктів при переробці корисних копалин і методів оцінки економічної ефективності. Виконано аналіз методів визначення та оцінки ефективності гідротехнічних систем технологій переробки мінеральної сировини, результати якого дозволили запропонувати нові параметри ефективності трубопровідних систем, що транспортують пульпи і зворотну технічну воду.

На підставі аналізу причин аварій і позапланових простоїв гідротранспорту виявлено перспективні напрями підвищення ефективності гідротехнічних систем технологій переробки мінеральної сировини. 3 урахуванням обраних напрямів запропоновано методи підвищення ефективності, які базуються на узгодженні параметрів і режимів роботи існуючих технологічних підсистем; на заміні капітального обладнання на більш досконале і на впровадженні спеціальних технологій, що підвищують ефективність окремих процесів.

\section{Бібліографічний список / Referernces}

1. Короленко М. К. Від водообороту на шламосховищах до сухого складування хвостів / М. К. Короленко, Г. Г. Губін, В. Г. Губіна // Наук.-техн. журнал. Відомості академії гірничих наук. - Кривий Ріг: ФО-П Чернявський Д. О., 2018. - Вип. 9. C. 31-40.

Korolenko M. K., Gubin G. G., Gubina V. G. Vid vodooborotu na shlamoshovischah do suhogo skladuvannya hvostiv. Nauk.-tehn. zhurnal. vidomosti akademiyi girnichih nauk. Kriviy rig, fo-p Chernyavskiy D. O., 2018, issue 9, pp. 31-40.

2. Обоснование параметров и режимов работы систем гидротранспорта горных предприятий / Ю. Д. Баранов, Б. А. Блюсс, Е. В. Семененко, 
В. Д. Шурыгин. - Днепропетровск: Новая идеология, 2006. - 416 с.

Baranov Yu. D., Blyuss B. A., Semenenko E. V., Shuryigin V. D. Obosnovanie parametrov i rezhimov rabotyi sistem gidrotransporta gornyih predpriyatiy. Dnepropetrovsk, Novaya ideologiya. 2006, 416 p.

3. Булат А. Ф. Модели элементов гидротехнических систем горных предприятий: монография / А. Ф. Булат, О. В. Витушко, Е. В. Семененко; Ин-т геотехнической механики им. Н. С. Полякова НАН Украины. - Днепропетровск: Герда, 2010. - 216 c.

Bulat A. F., Vitushko O. V., Semenenko E. V. Modeli elementov gidrotehnicheskih sistem gornyih predpriyatiy. IGTM NAN Ukraine. Dnepropetrovsk, Gerda. 2010, 216 p.

4. Вайнштейн Б. С. Экономика трубопроводного гидротранспорта. Проблемы, противоречия, задачи / Б. С. Вайнштейн / / Экономическая эффективность трубопроводного гидротранспорта. - М.: ВНИИПИгидротрубопровод, 1986. C. 8-18.

Vaynshteyn B. S. Ekonomika truboprovodnogo gidrotransporta. Problemyi, protivorechiya, zadachi. Ekonomicheskaya effektivnost truboprovodnogo gidrotransporta. Moscow, VNIIPIgidrotruboprovod. 1986, pp. 8-18.

5. Степанов В. С. Определение эффективности использования энергии в транспортных системах на основе энергетического и эксергетического КПД (на примере трубопроводного транспорта) / В. С. Степанов, Т. Б. Степанова / / Изв. Вузов. Проблемы энергетики. - 2000. - № 9-10. - С. 126132.

Stepanov V. S., Stepanova T. B. Opredelenie effektionosti ispolzovaniya energii $v$ transportnyih sistemah na osnove energeticheskogo i eksergeticheskogo KPD (na primere truboprovodnogo transporta). Izv. Vuzov. Problemyi energetiki. 2000, no. 9-10, pp. 126132.

6. Покровская В. Н. Трубопроводный транспорт в горной промышленности / В.Н.Покровская. - М.: Недра, 1985. - 191 с.

Pokrovskaya, V. N. Truboprovodnyiy transport $v$ gornoy promyishlennosti. Moscow, Nedra. 1985, 191 p.

7. Воронов В. А. Снижение энергоемкости гидротранспортирования хвостов обогащения горных предприятий оптимизацией режимов работы грунтовых насосов и гравитационных сгустителей: дис. ... канд. техн. наук 05.05.06 Горные машины / В. А. Воронов. - СанктПетербург, 2007. - 190 с.

Voronov V. A. Snizhenie energoemkosti gidrotransportirovaniya hoostov obogascheniya gornyih predpriyatiy optimizatsiey rezhimov rabotyi gruntovyih nasosov i gravitatsionnyih sgustiteley: dissertatsiya kandidata tehnicheskih nauk 05.05.06 - Gornyie mashinyi. Sankt-Peterburg. 2007, 190 p.

8. Сухарев М. Г. Технологический расчет и обеспечение надежности газо- и нефтепроводов / М. Г. Сухарев, А. М. Карасевич. - М.: МГГУ, 2000. 209 c.

Suharev M. G., Karasevich A. M. Tehnologicheskiy raschet $i$ obespechenie nadezhnosti gazo- $i$ nefteprovodov. Moscow, MGGU. 2000, 209 p.

9 Земенкова М. Ю. Системный мониторинг показателей надежности объектов трубопроводного транспорта: автореф. дис. ... канд. техн. наук, 05.13.01 - Системный анализ, управление и обработка информации (нефтегазовой отрасли) / Мария Юрьевна Земенкова. - Тюмень, 2007. - 18 с.

Zemenkova, M.Yu. Sistemnyiy monitoring pokazateley nadezhnosti ob'ektov truboprovodnogo transporta: Avtoreferat dissertatsii na soiskanie uchenoy stepeni kandidata tehnicheskih nauk, 05.13.01 - Sistemnyiy analiz, upravlenie i obrabotka informatsii (neftegazovoy otrasli). Tyumen. 2007, $18 \mathrm{p}$.

Цель. Обоснование параметров эфрфективности функционирования гидротехнических систем в технологиях добычи и переработки минерального сырья с учетом современных возможностей интенсифрикации процессов переработки полезных ископаемых.

Методика. Анализ результатов исследования режимов работы гидротехнических систем предприятий горно-металлургической отрасли позволил обосновать параметры гидравлических процессов в технологиях переработки минерального сырья с целью повышения эфффективности параметров обогатительного оборудования и снижения себестоимости готового концентрата.

Результаты. Обоснованы параметры эфффективности гидротехнических систем предприятий горнометаллургической отрасли Украины, а именно в результате развития методов оценки эфффективности гидротранспортного комплекса перерабатывающих комбинатов предложено характеризовать надежность поставок продукции и сохранность системы трубопроводного транспорта величиной показателя гидравлической надежности.

Научная новизна. На основе методов оценки экономической эффрективности гидротехнических систем технологий переработки минерального сырья, исходными принципами которой являются: комплексность оценки; коммерческий подход; применение адекватных параметров определения эфффективности на различных организационных уровнях; учет фрактора времени и фрактора неопределенности предложен интегральный показатель, а именно показатель гидравлической надежности.

Практическая значимость. Заключается в введении следующих показателей: гидравлической надежности и режимов транспортирования в гидротехнических системах в систему мониторинга технологий переработки минерального сырья обеспечивает непрерывный контроль в автоматиче- 
ском режиме с учетом возможных непрогнозируемых изменений свойств перекачиваемой среды, производительности и других параметров, поскольку величина потерь напора выражается через гидравлический уклон, зависит от скорости и плотности гидросмеси, которая транспортируется.

Ключевые слова: гидротехнические системы, технологии обогащения минерального сырья, коэффрициент гидравлической надежности, экономическая эфроективность.

Purpose. The efficency parameters substantiation of hydraulic systems functioning in the extraction technologies and mineral raw materials processing, taking into account modern possibilities of intensifying the processes of mineral processing.

Methodology. The analysis results of the research operating modes hydraulic engineering systems mining and metallurgical enterprises enabled to substantiate the parameters of hydraulic processes in the technologies of processing mineral raw materials in order to increase the efficiency parameters enrichment equipment and reduce the cost of finished concentrate.

Findings. Proved parameters of the efficiency hydraulic engineering systems enterprises the mining and metallurgical industry in Ukraine, namely, as a result of the development methods for assessing the efficiency of hydrotransport complex processing plants, are proposed to characterize the reliability of supply products and the safety of pipeline transport system by the value of hydraulic reliability index.
Originality. On the basis methods for assessing the economic efficiency hydraulic engineering systems, the processing of mineral raw materials, the starting principles of which are: complexity of evaluation; commercial approach; application of adequate parameters for determining the efficiency at different organizational levels; Considering the factor of time and the factor of uncertainty, an integral index is proposed, namely, the index of hydraulic reliability.

Practical value. Practical significance is the following introduction of indicators: indicators of hydraulic reliability and modes of transportation in hydraulic systems in the monitoring system for the processing of mineral raw materials provides continuous monitoring in the automatic mode, taking into account possible unpredictable changes in the properties of the pumped environment, productivity and other parameters, since the magnitude of losses the pressure is expressed through the hydraulic slope, which depends on the speed and density of the hydraulic mixture that is transported.

Key words: hydrotechnical systems, mineral resources enrichment technologies, hydraulic reliability coefficient, economic efficiency.

Рекомендована к публикации д. т. н. И. А. Садовенко

Поступила 1.10.2018

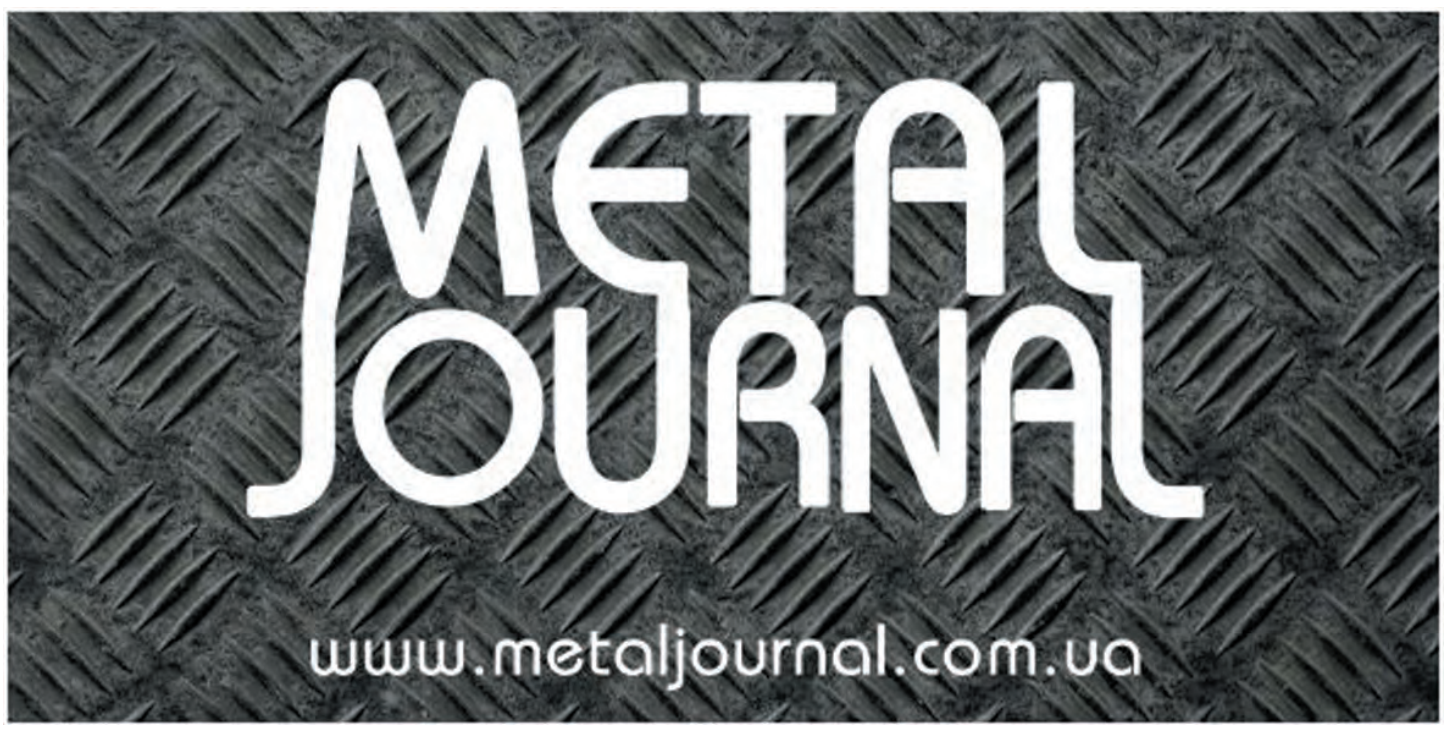

